\title{
Analyzing the Embedded Learning-Based Movement Education Program's Effects on Preschool Children's Visual-Motor Coordination and Self-Regulation
}

\author{
Gokhan Duman ${ }^{1} \&$ Fatma Ozkur ${ }^{2}$ \\ ${ }^{1}$ Gazi Education Faculty, Gazi University, Ankara, Turkey \\ ${ }^{2}$ Nisantasi Vocational School, Nişantasi University, Istanbul, Turkey \\ Correspondence: Fatma Ozkur, Nisantasi Vocational School, Nisantasi University, Sogutozu Maslak Istanbul, \\ Turkey. E-mail: fatmaoz.edu@gmail.com
}

Received: August 10, 2019

Accepted: September 5, 2019

Online Published: September 20, 2019

doi:10.5539/jel.v8n5p193

URL: https://doi.org/10.5539/jel.v8n5p193

\begin{abstract}
Preschool children's visual-motor coordination skills are very valuable for their academic and social learnings. Using these skills, children have a broad movement repertoire, display better academic skills, participate in classroom activities and social relations, and develop self-regulation. Self-regulation is required for children to set their goals, purposeful planning, monitoring, and adapting. Children are natural players and they enjoy to move and play. Early childhood programs should consider supporting the visual-motor coordination in joint play situations to enhance children's behaviors. This study used movement activities designed with embedded learning instruction to create cooperative play and increased group interactions among children. The purpose of this research was to analyze the embedded learning-based movement education program's effects on preschool children's visual-motor coordination and self-regulation development. For this purpose, an experimental research design with pretest-posttest, control group constructed. Control group children followed their traditional (MoNE, 2013) preschool education program while the experiment group pursued embedded learning-based movement education. Results indicated that both groups of children had significantly better $(p . \leq .0 .05)$ visual-motor coordination and self-regulation skills. The difference was greater in experience group of children and the correlation was stronger between visual-motor coordination and self-regulation. It has been found that embedded learning-based movement education program positively affected preschool children's visual-motor coordination and self-regulation.
\end{abstract}

Keywords: preschool, embedded, visual-motor, self-regulation

\section{Introduction}

Early childhood education aims to support children's entire development areas and give them the right behavior. This establishment brings positive outcomes to a child's school life and future (Sparling, Ramey, \& Ramey 2007). It has been known that children's visual-motor coordination skills grow rapidly during the early years of life (Dere, 2019). Identifying and improving visual-motor coordination skills during this term will lay the foundation for proper brain function and development as children grow. Visual-motor coordination is the degree to which visual perception and finger-hand movements are well coordinated (Beery \& Beery, 2010). For young children, visual-motor coordination skills allow them to successfully play sports, completely different types of puzzles, cut and fold paper, color in the lines, and write legibly, all of which help kids gain confidence in the classroom. However, this coordination functions in a wider skill area such as crawling, walking, and running, avoiding dangers, eating, drawing, painting, reading and writing, using computers, constructing buildings, using tools and discovering (Daly et al., 2003). Deficiencies or delays in visual-motor coordination skills cause some problems in acquiring academic skills, participating in school activities, social relations and self-concept (Dankert et al., 2003; Case-Smith, 2005). Besides its importance on movement and fine motor skills related tasks, it has been stated that visual-motor coordination may predict improved learning-related behaviors as well as better self-regulation skills (Sezgin \& Demiriz, 2016; Purtaş \& Duman, 2017a).

Self-regulation is a multidimensional phenomenon in which an individual exhibits appropriate and effective use of cognitive and metacognitive strategies for meeting the demands of specific tasks (Pintrich, 2000). 
Self-regulation helps children for their goal setting and planning, monitoring, and adapting performance and effective evaluation (Boekaerts, 1999). It is characterized by an intrinsic motivational orientation, where the individual seeks challenge, persists despite difficulties, and interprets difficulties as opportunities for further learning (Zimmerman, 2002). Without proper motor control, children will most likely be isolated from other children, which could engender feelings of aggression as well as deny them the opportunity to practice prosocial skills (Duman, 2016). On the other hand, better motor control facilitates joint play among peers. It also allows children to follow directions and remain engaged during games. Furthermore, children with better motor control are likely to be viewed as more compliant by teachers, and children perceived as more compliant typically have higher-quality relationships with teachers and are better liked by peers (Hughes, Cavell, \& Willson, 2001). These experiences are necessary for the development of self-regulation skills.

Early childhood education programs are expected to be designed to improve the perceptual, motor and cognitive functioning of preschool children, and ultimately influence school readiness to learn in the school environment (Anderson, et al., 2003). However, very few of them change, alter or adapt alternative methods to improve their curriculum (Özkür, 2019; Koyunlu Ünlü \& Dere, 2019). It has also been observed that the function of the early childhood education is shifting to become more academic and less play-oriented (Irwin, 2017). Yet, early childhood programs should consider supporting the visual-motor coordination in joint play situations to enhance children's behaviors (Purtaş \& Duman, 2017b; Sezgin, 2016).

Embedded instruction is one of the naturalistic teaching approaches that has been suggested to use in the guidelines of developmentally appropriate practices for young preschool children (Bredekamp \& Copple, 1997). Embedding is defined as a process that occurs across daily activities (child-directed, routine, and planned), offering multiple and varied learning opportunities that in turn elicit desired responses from children (Pretti-Frontczak \& Bricker, 2004; Rakap, 2017). The embedding of learning opportunities has been used to target goals and objectives on individualized educational plans of young children with disabilities in inclusive preschool classrooms (Noh, Allen, \& Squires, 2009). Studies showed that both typical and atypical children's fine motor, gross motor, adaptation, social-emotional and cognitive skill developments are improved remarkably using embedded instruction (Macy \& Bricker, 2007). Because of these benefits, the use of embedded teaching instruction has been become prevalent in both general and inclusive preschool settings (Snyder, Rakap, Hemmeter, McLaughlin, Sandall, \& McLean, 2015; Cole vd., 2004; McDonnell, Thorson, Disher, Mathot-Buckner, Mendel, \& Ray, 2003). Embedded instruction provides opportunities for early childhood education practitioners to establish play-based interactions, support motor development, and learning. Because there are time restrictions and safety precautions in the nature of the routines and transitions, the majority of the embedded learning experiences are grounded in play activities (Snyder, Denney, Pasia, Rakap, \& Crowe, 2011). For this study, embedded learning-based movement education program was developed by play activities that required movement and cooperative play in small and large groups of children. The goals and objectives were embedded in circle times and play activities. The present study addresses the effectiveness of the embedded learning-based movement education program on preschool children's visual-motor coordination and self-regulation.

\section{Methods}

\subsection{Research Model}

The model of this research was experimental design with pretest-posttest, control group. Pretest-posttest designs are widely used in behavioral research, primarily to compare groups and/or measuring change resulting from experimental treatments (Dimitrov \& Rumrill, 2003).

Table 1. Research model

\begin{tabular}{llll}
\hline Group & Pretest & Process & Posttest \\
\hline Experiment & $T_{1}$ & $\begin{array}{l}\text { Embedded Learning-Based } \\
\text { Movement Education Program }\end{array}$ & $T_{3}$ \\
Control & $T_{2}$ & $\begin{array}{l}\text { Traditional MoNE } \\
\text { Preschool Education Program }\end{array}$ & $T_{4}$ \\
\hline
\end{tabular}

Note. $T=$ Test.

Both the experiment and control groups were assessed at two different time points (beginning and final). Pretests were applied to experiment and control groups before the beginning of the education programs. Experiment group children followed embedded learning-based movement education program and control group children 
followed the traditional Ministry of National Education (MoNE, 2013) preschool education program for twelve weeks. Posttests were applied after completion of education programs.

\subsection{Study Group}

This study aimed to analyze preschool children's visual-motor and self-regulation skills. Purposive sampling method was preferred for the determination of the study group. One preschool which voluntarily agreed to participate in the study in Istanbul was chosen. Following traditional (MoNE) education program, having two separate classrooms for the five-year-olds children, having middle socio-economic level, having consent form from all the parents, having available physical environment for the new program were taken into account for the sampling process. 30 children were participated in the study. The experiment group consisted of 15 children (7 girls and 8 boys) and the control group consisted of 15 children ( 7 girls and 8 boys). The average age of the children was 65 months and 2 days for the experiment group and 65 months and 15 days for the control group.

\subsection{Embedded Learning-Based Movement Education Program}

Embedded learning-based movement education program was developed for the five years old children. The general objective of the program was supporting children's visual-motor and self-regulation skills. For this purpose, movement activity plans using an enjoyable learning process were formed. The movement activities were designed requiring large motor, fine motor and visual-motor coordination skills in the play structure. Small group activities, cooperative play, and social interactions were embedded in the activities to complete the naturally occurred tasks and/or needs during play. Situations such as failing, observing other's and other's products, comparing movements or products, measuring and comparing peers' movements or products, observation, timekeeping, using original product or model for comparison, and formulating ideas were embedded in the play process as well. It was expected that children regulate their behaviors naturally in the cooperative learning process and interaction. Parkour models (Duman, 2016) were used to establish children's motor skills in the activity. Each parkour model had a situation requiring cooperative play. The products or materials achieved during parkour were necessary for the next partition of the play. Activities in this next partition of the plays were formed to naturally require attentiveness of the children and fine motor skills. Because there are several steps and partitions in a play process, integrated activity format was used. Each activity was planned to take 45-60 minutes. The sequences of the activities were planned to be a construction of the next activity. The planning of the activities was formed in four main section: Format (name of the activity, time, age group, parkour model, and materials), targets and goals (movement development, and self-regulation), learning process (circle time, play and evaluation), and parkour (motor tasks and cooperative play).

The targets and goals of the activities were determined to contribute to children's motor skills and behavior modification. The course of an activity had three sub-dimensions (circle time, play and evaluation). Activity was introduced to the children in circle time. Introductory knowledge, concepts, videos, magazines, and books related to play situations were supplied to children in circle time. Play was where children engage in play and play through the episodes in a natural context. Evaluation was where children try to remember the play episodes and/or situations. Each evaluation dimension had a passive completing activity to help children to embody the whole learning process.

\subsection{Data Collection Tools}

Beery-Buktenica Developmental Visual-Motor Coordination Test was used to measure children's visual-motor integration levels. This test was developed by Beery, Buktenica, and Beery (2010) and it was adapted to Turkish by Demirler (2016). There are three sub-categories including visual perception, motor coordination and visual-motor coordination in the test. There are thirty items in each category and wrong answers are given 0 and right answers are given 1 point in the test. The maximum score of 30 points can be achieved by a child.

Child Behavior Rating Scale was used to determine children's self-regulation skills. This scale was developed by Bronson, Goodson, Layzer, and Love (1990) and adapted to Turkish by Sezgin (2016). There are two sub-categories in the scale including behavior modification and social skills. Five-point Likert type scale was (1-never, and 5-always) applied for each item. The maximum score of 85 points can be achieved by a child.

\subsection{Data Collection and Analysis}

The researcher was involved in six educational activities of the experiment group in two weeks before collecting data. Before the pretest phase and application of embedded learning-based movement education program, a meeting held with parents and teachers to inform them about the study. For the pretest and posttest phase, both experiment and control group children's visual-motor coordination data were collected using Beery Buktenica Developmental Visual Motor Coordination Test. Data regarding the same children's self-regulation skills were 
collected using the Child Behavior Rating Scale.

Data were coded and analyzed using a statistic program for social sciences. Minimum and high scores, arithmetic means and standard deviations scores of experiment and control group children were presented for descriptive analyses purposes. The normality of the scores was tested using Shapiro-Wilks test. This test is recommended to use when there are less than 50 participants in the study (Abbott, 2011). One of the non-parametric tests, Mann-Whitney U, was applied for comparative analyses. This test is suggested to use analyzing significant differences between two (experiment and control) groups' scores as a non-parametric test (Kalayc1, 2008). Spearman Correlation Coefficient test was used to analyze if there was a significant correlation between visual-motor coordination and self-regulation development of children. This test is also put in place for determining correlation scores of the non-normal distributions (Abbott, 2011). Confidence level was set to 95\% $(p . \leq 0.05)$ for all types of analyses explained above. Table 2 presents the correlation values and significances used in this study.

Table 2. Spearman correlation values and level of significances

\begin{tabular}{ll}
\hline Correlation Value & Significance \\
\hline $\mathrm{r} .<0.2$ & Very weak \\
$0.2-0.4$ & Weak \\
$0.4-0.6$ & Moderate \\
$0.6-0.8$ & Strong \\
$0.8>$.r & Very Strong \\
\hline
\end{tabular}

\section{Results}

The purpose of this study was to analyze the embedded learning-based movement education program's effects on preschool children's visual-motor coordination and self-regulation. For this purpose, embedded learning-based movement education program applied to the experiment group while the control group followed its traditional preschool education program. Table 3 presents the descriptive analysis of the control and experiment group of children's visual-motor coordination development.

Table 3. Visual-motor coordination levels of kindergarten children

\begin{tabular}{llllll}
\hline Group & Test & $\boldsymbol{n}$ & Score & $\overline{\boldsymbol{x}}$ & $\boldsymbol{s} \boldsymbol{d}$ \\
\hline Control & Pretest & 15 & 212.00 & 14.13 & 1.81 \\
& Posttest & 15 & 232.00 & 15.47 & 2.26 \\
Experiment & Pretest & 15 & 222.00 & 14.80 & 1.74 \\
& Posttest & 15 & 275.00 & 18.33 & 2.35 \\
\hline
\end{tabular}

Table 3 shows the visual-motor coordination levels of the kindergarten children in control and experiment groups. The control group achieved 212 points for the pretest and 232 points for the posttest. The arithmetic mean score of the visual-motor coordination skills of the control group children was found as 14.13 for the pretest and 15.47 for the posttest. The experiment group achieved 222 points for the pretest and 275 points for the posttest. The arithmetic mean score of the visual-motor coordination skills of the experiment group children was found as 14.80 for the pretest and 18.33 for the posttest. Results indicated that two groups' visual-motor coordination skill levels were very similar at the beginning level.

Table 4. Self-regulation levels of kindergarten children

\begin{tabular}{llllll}
\hline Group & Test & $\boldsymbol{n}$ & Total & $\overline{\boldsymbol{x}}$ & $\boldsymbol{s} \boldsymbol{d}$ \\
\hline \multirow{2}{*}{ Control } & Pretest & 15 & 1016 & 67.73 & 8.56 \\
& Posttest & 15 & 1052 & 70.13 & 10.33 \\
Experiment & Pretest & 15 & 1020 & 68.00 & 8.61 \\
& Posttest & 15 & 1201 & 80.10 & 7.22 \\
\hline
\end{tabular}

Table 4 shows self-regulation levels of children in control and experiment groups obtained by child behavior rating scale. Control group children achieved 1016 points for the pretest and 1052 points for the posttest. The 
arithmetic mean scores of the control group were found as 67.73 for the pretest and 70.13 for the posttest. Experiment group children achieved 1020 points for the pretest and 1201 points for the posttest. The arithmetic mean scores of experiment group were found as 68.00 for the pretest and 80.10 for the posttest. Results indicated that two groups' self-regulation skill levels were very similar at the beginning of the study.

Table 5. Normality test of the visual-motor development scores

\begin{tabular}{lllll}
\hline Group & Test & N & Shapiro-Wilk & $\boldsymbol{P}$ \\
\hline Control & Pretest & 15 & .866 & $.029^{*}$ \\
& Posttest & 15 & .872 & $.036^{*}$ \\
Experiment & Pretest & 15 & .865 & $.028^{*}$ \\
& Posttest & 15 & .866 & $.029^{*}$ \\
\hline
\end{tabular}

Note. p. $\leq .0 .05$.

Table 5 shows the results from the Shapiro-Wilk test of normality for visual-motor development scores. The significance value of control group children was found as .029 for the pretest and .036 for the posttest. It was found as .028 for the pretest and .029 for the posttest for the experiment group. Results indicated that visual-motor development test scores achieved from both control and experiment groups did not present a normal distribution $(p . \leq .0 .05)$. Therefore, non-parametric measures should be applied for further analysis.

Table 6. Normality test of children's self-regulation scores

\begin{tabular}{lllll}
\hline Group & Test & N & Shapiro-Wilk & $\boldsymbol{P}$ \\
\hline Control & Pretest & 15 & .868 & $.032^{*}$ \\
& Posttest & 15 & .865 & $.029^{*}$ \\
Experiment & Pretest & 15 & .861 & $.025^{*}$ \\
& Posttest & 15 & .846 & $.015^{*}$ \\
\hline
\end{tabular}

Note. $p . \leq 0.05$.

Table 6 shows the results from the Shapiro-Wilk test of normality for self-regulation scores. The significance value of control group children was found as .032 for the pretest and .029 for the posttest. It was found as .025 for the pretest and .015 for the posttest for the experiment group. Results indicated that child behavior rating scale scores achieved from both control and experiment groups did not present a normal distribution $(p . \leq .0 .05)$. Therefore, non-parametric measures should be applied for further analysis.

Table 7. Mann whitney u test results of the pretest and posttest scores of the visual-motor development in control and experiment groups

\begin{tabular}{|c|c|c|c|c|c|c|c|}
\hline Visual-Motor & & Group & $\mathbf{n}$ & Rank Mean & Rank Total & $\mathbf{U}$ & $\mathbf{P}$ \\
\hline \multirow[t]{6}{*}{ Coordination } & Pretest & Control & 15 & 13.77 & 206.50 & 86.500 & .285 \\
\hline & & Experiment & 15 & 17.23 & 258.50 & & \\
\hline & & Total & 30 & & & & \\
\hline & Posttest & Control & 15 & 10.70 & 160.50 & 40.500 & $.003 *$ \\
\hline & & Experiment & 15 & 20.30 & 304.50 & & \\
\hline & & Total & 30 & & & & \\
\hline
\end{tabular}

Note. p. $\leq .0 .05$.

Table 7 shows control and experiment groups' Mann Whitney U test results of visual-motor development scores for the pretest and posttest. The rank mean and rank total of control group children were found as 13.77 and 206.50 in the pretest. These values were found as 17.23 and 258.50 for the experiment group. The significance value $(p)$ was found as .285. According to the Mann Whitney $\mathrm{U}$ test results, there was no significant difference between the pretest scores of the children's visual-motor development in the control and experiment groups (p. $\geq .0 .05)$. It can be determined that children in both groups had similar visual-motor development level at the beginning of the study.

On the other hand, the rank mean and rank total of control group children was found as 10.70 and 160.50 in the posttest. These values were found as 20.30 and 304.50 for the experiment group. The significance value $(p)$ was 
found as .003 . According to the Mann Whitney $U$ test results, there was a significant difference between the posttest scores of the children's visual-motor development in the control and experiment groups $(p . \leq .0 .05)$. It can be resolved that children in the experiment group following embedded learning-based movement education program had better visual-motor development.

Table 8. Mann whitney u test results of the pretest and posttest scores of the child behavior rating scale in control and experiment groups

\begin{tabular}{llllllll}
\hline Self-Regulation & & Group & n & Rank Mean & Rank Total & U & P \\
\cline { 2 - 7 } & Pretest & Control & 15 & 15.93 & 239.00 & 106.00 & .787 \\
& & Experiment & 15 & 15.07 & 226.00 & & \\
& Total & 30 & & & & \\
& \multirow{2}{*}{ Posttest } & Control & 15 & 11.70 & 175.50 & 55.50 & $.016^{*}$ \\
& & Experiment & 15 & 19.30 & 289.50 & & \\
\hline
\end{tabular}

Note..$\leq .0 .05$.

Table 8 shows control and experiment groups' Mann Whitney U test results of child behavior rating scale scores for the pretest and posttest. The rank mean and rank total of control group children were found as 15.93 and 239 in the pretest. These values were found as 15.07 and 226 for the experiment group. The significance value $(p)$ was found as .787. According to the Mann Whitney $U$ test results, there was no significant difference between the pretest scores of the children's child behavior rating scale in the control and experiment groups ( $p . \geq .0 .05)$. It can be said that children in both groups had similar self-regulation skill level at the beginning.

On the other hand, the rank mean and rank total of control group children were found as 11.70 and 175.50 in the posttest. These values were found as 19.30 and 289.50 for the experiment group. The significance value $(p)$ was found as .016. According to the Mann Whitney $U$ test results, there was a significant difference between the posttest scores of the children's child behavior rating scale in the control and experiment groups $(p . \leq .0 .05)$. It can be stated that children in the experiment group had a better self-regulation skill level after the embedded learning-based movement education program.

Table 9. Wilcoxon signed rank test results regarding the pretest and posttest scores of the children's visual-motor development in control and experiment groups

\begin{tabular}{llllllll}
\hline $\begin{array}{l}\text { Visual-Motor } \\
\text { Coordination }\end{array}$ & Group & $\begin{array}{l}\text { Pretest- } \\
\text { Posttest }\end{array}$ & $\mathbf{n}$ & Ranking Average & Ranking Sum & $\mathbf{Z}$ & P \\
\cline { 2 - 8 } & Control & Negative Ranking & 0 & 0.00 & 0.00 & -3.270 & $.001^{*}$ \\
& & $\begin{array}{l}\text { Positive Ranking } \\
\text { Experiment }\end{array}$ & 13 & 7.00 & 91.00 & & \\
& Equal & 2 & & & 0.00 & -3.424 & $.001^{*}$ \\
& Negative Ranking & 0 & 0.00 & 120.00 & & \\
\hline & Positive Ranking & 15 & 8.00 & & & \\
\hline
\end{tabular}

Note. p. $\leq .0 .05$.

Table 9 shows control and experiment groups children's Wilcoxon Signed Rank test results of visual-motor development scores. The significance value $(p)$ was found as .001 and the $z$ score was found as -3.270 for the control group. It was observed that there was a significant ( $p . \leq .0 .05)$ difference between pretest and posttest scores of the control group children. It can be understood from the posttest scores that control group children's, following traditional (MoNE) education program, visual-motor coordination skills were developed.

On the other hand, the significance value $(p)$ was found as .001 and the $z$ score was found as -3.424 for the experiment group. It was understood that there was a significant $(p . \leq .0 .05)$ difference between pretest and posttest scores of the experiment group children. This difference was also in favor of the posttest scores. It can be determined that experiment group children's, following embedded learning-based movement education program, visual-motor coordination skills were developed. The positive ranking scores (91 for the control group and 120 for the experiment group) indicated that the development was higher in the experiment group of children. 
Table 10. Wilcoxon signed rank test results regarding the pretest and posttest scores of the child behavior rating scale in control and experiment groups

\begin{tabular}{|c|c|c|c|c|c|c|c|}
\hline \multirow[t]{7}{*}{ Self-Regulation } & Group & $\begin{array}{l}\text { Pretest- } \\
\text { Posttest }\end{array}$ & $\mathbf{n}$ & Ranking Average & Ranking Sum & $\mathbf{Z}$ & $\mathbf{P}$ \\
\hline & Control & Negative Ranking & 1 & 8.50 & 8.50 & -2.615 & $.009 *$ \\
\hline & & Positive Ranking & 12 & 6.88 & 82.50 & & \\
\hline & & Equal & 2 & & & & \\
\hline & Experiment & Negative Ranking & 1 & 1.50 & 1.50 & -3.326 & $.001 *$ \\
\hline & & Positive Ranking & 12 & 8.46 & 118.50 & & \\
\hline & & Equal & 2 & & & & \\
\hline
\end{tabular}

Note. $p . \leq .0 .05$.

Table 10 shows control and experiment groups children's Wilcoxon Signed Rank test results of child behavior rating scale scores. The significance value $(p)$ was found as .009 and the $z$ score was found as -2.615 for the control group. It was observed that there was a significant ( $p . \leq .0 .05)$ difference between pretest and posttest scores of the control group children. This difference was in favor of the posttest scores. It can be deduced that control group children's, following traditional (MoNE) education program, behavior skills were developed.

On the other hand, the significance value ( $p$ ) was found as .001 and the $z$ score was found as -3.326 for the experiment group. It was obtained that there was a significant $(p . \leq .0 .05)$ difference between pretest and posttest scores of the experiment group children. This difference was also in favor of the posttest scores. It can be understood that experiment group children's, following embedded learning-based movement education program, behavior skills were developed. The positive ranking scores ( 82.50 for the control group and 118.50 for the experiment group) indicated that the progress was higher in the experiment group of children.

Table 11. Spearman's rank order correlation of control group children's scores

\begin{tabular}{lllll}
\hline Variable & $\mathbf{n}$ & $\boldsymbol{r}$ & $\boldsymbol{p}$ \\
\hline Visual-motor coordination & & & \\
Child behavior rating & 15 & .583 & $.023^{*}$ \\
\hline
\end{tabular}

Note. p. $\leq .0 .05$.

Table 11 shows the Spearman Rank Order correlation value of control group children's visual-motor coordination and child behavior rating scale scores. The correlation value $(r)$ was found as .583 with the significance value $(p)$ of .023 . Results indicated that there was a moderate level correlation between visual-motor coordination development and behavior development of the control group children following traditional (MoNE) education program.

Table 12. Spearman's rank order correlation of experiment group children's scores

\begin{tabular}{llll}
\hline Variable & $\mathbf{n}$ & $\boldsymbol{r}$ & $\boldsymbol{p}$ \\
\hline Visual-motor coordination & & & .632 \\
Child behavior rating & 15 & $.018^{*}$ \\
\hline
\end{tabular}

Note. p. $\leq .0 .05$.

Table 12 shows the Spearman Rank Order correlation value of experiment group children's visual-motor coordination and child behavior rating scale scores. The correlation value $(r)$ was found as .632 with the significance value $(p)$ of .018 . Results indicated that there was a strong level correlation between visual-motor coordination development and behavior development of the experiment group children following embedded based movement education program. These results revealed that the correlation between two developmental aspects in experiment group was higher comparing control group children.

\section{Conclusion and Discussion}

The purpose of this study was to examine the effectiveness of the embedded learning-based movement education program on preschool children's visual-motor coordination and self-regulation. Whether there was a correlation 
between visual-motor development and self-regulation was also examined. For these purposes, control group children followed their traditional (MoNE, 2013) preschool education program while experiment group children followed the embedded learning-based movement education program for twelve weeks. Both two groups' assessments were completed at the beginning and the final phase of the study.

It has been found that preschool children participated in this study had similar visual-motor coordination and self-regulation skills at the beginning of the study. There are several studies (Görener, 2006; Ercan \& Aral, 2011; Demirler \& Ar1, 2016) measuring visual-motor coordination level and capacity of typically developing preschool children These studies indicated similar visual-motor coordination levels for the typical preschool children with the current study. Besides, both control and experiment group children's visual-motor skills were developed during the study. When other study results were considered, it can be stated that visual-motor coordination is affected by both natural development and education. This study showed that development in visual-motor coordination was greater in experiment group. It can be explained that using motor functions of the children as a tool to teach several behaviors such as cooperative performance raised their visual-motor coordination level.

There are also studies investigating self-regulation skills of the typical developing preschool children (Sezgin \& Demiriz, 2016; Ogan, 2005). These studies revealed similar self-regulation skill levels following this study. They also presented that children have better behavioral skills when they have more interaction and play enjoyable games (Rueda, Rothbart, Mc Candliss, Saccomoanno, \& Posner, 2005). The current study indicated that movable play situations including a major purpose with along minor challenging situations designed for preschool children using embedded instruction, increased children's self-regulation skills. This progress was greater in embedded learning-based movement education program comparing to the traditional MoNE program. When children act together and solve problems collectively, their behavioral skills are developed positively. Movement is a natural need, especially for young aged children. This study showed that movement can be used for making activities more enjoyable and catchier. Results also revealed that there was a positive correlation between visual-motor coordination and self-regulation skills of preschool children as well. Visual-motor coordination in one of the key components of all motor functions. When motor functions work properly to complete a task, children get better possibilities to improve their behavior as well.

According to gained outcomes, movement contains valuable elements to encourage preschool children's visual-motor coordination and self-regulation skills. Using embedded learning-based instruction in movement activities sustains to achieve pre-planned achievements during an activity. It has been found that embedded learning-based movement education program positively affected preschool children's visual-motor coordination and self-regulation. As a conclusion, movement activities and embedded learning instruction should be taken into consideration to support preschool children's motor development and self-regulation skills.

\section{References}

Abbott, M. L. (2011). Understanding educational statistics using: Microsoft Excel and SPSS. United States: John Wiley \& Sons, Inc.

Anderson, J. C., Funk, J. B., Elliot, R., \& Smith, P. H. (2003). Parental support and pressure and children's extracurricular activities: relationships with amount of involvement and affective experience of participation. Journal of Applied Developmental Psychology, 24(2), 241-257. https://doi.org/10.1016/S0193-3973(03)00046-7

Beery, K., Buktenica, N., \& Beery, N. (2010). Beery-Buktenica Developmental Test of Visual-Motor Integration (6th ed., BEERYTM VMI). Pearson. https://doi.org/10.1037/t48947-000

Boekaerts, M. (1999). Self-regulated with respect to informal learning. International Journal of Educational Research, 31, 533-544. https://doi.org/10.1016/S0883-0355(99)00020-8

Bredekamp, S., \& Copple, C. (1997). Developmentally Appropriate Practice in Early Childhood Programs (Revised ed.). Washington, DC: NAEYC.

Bronson, M., B., Goodson, B. D. L., Jean, I., \& Love, J. M. (1990). Child Behavior Rating Scale. Cambridge, MA: Abt Associates.

Case-Smith, J. (2005). Occupational therapy for children. St. Louis: Elsevier Mosby.

Cole, P. M., Martin, S. E., \& Dennis, T. A. (2004). Emotion regulation as a scientific construct: methodological challenges and directions for child development research. Child Development, 317-333. https://doi.org/10.1111/j.1467-8624.2004.00673.x

Daly, C. J., Kelley, G. T., \& Krauss, A. (2003). Relationship between visual-motor integration and handwriting 
skills of children in kindergarten: A modified replication study. American Journal of Occupational Therapy, 57, 459-462. https://doi.org/10.5014/ajot.57.4.459

Dankert, H. L., Davies, P. L., \& Gavin, W. J. (2003). Occupational theraphy effects on visual-motor skills in preschool. The American Journal of Occupational Theraphy, 57, 542-549. https://doi.org/10.5014/ajot.57.5.542

Demirler, Ö. F. (2016). 36-79 ayllk çocuklar üzerinde uygulanan Beery-Buktenika gelişimsel görsel motor koordinasyon testinin geçerlik ve güvenirlik çalışması. Yayımlanmamış yüksek lisans tezi, Okan Üniversitesi, İstanbul.

Demirler, Ö. F., \& Arı, M. (2018). Beery-Buktenika gelişimsel görsel motor koordinasyon testinin 36-79 aylık çocuklara uyarlanması. Turkish Journal of Primary Education, 3(1), 01-18.

Dere, Z. (2019). Analyzing the early literacy skills and visual motor integration levels of kindergarten students. Journal of Education and Learning, 8(2), 176-181. https://doi.org/10.5539/jel.v8n2p176

Dimitrov, D. M., \& Rumrill, PD Jr. (2003). Pretest-posttest designs and measurement of change. Work, 20(2), $159-165$.

Duman, G. (2016). Okul öncesi eğitimde beden eğitimi ve oyun. Ankara: Eğiten.

Ercan, Z. G., \& Aral, N. (2011). Beery- Buktenica gelişimsel görsel motor koordinasyon testinin altı yaş (60-72 ay) Türk çocuklarına uyarlanması. Hacettepe Üniversitesi Ĕ̈itim Fakültesi Dergisi, 41, 136-145.

Görener, Ö. (2006). Beş-altı yaş grubu çocuklarda yapılandırılmış görsel sanat eğitiminin görsel algılamaya etkisinin incelenmesi. Yüksek lisans tezi, Hacettepe Üniversitesi Sağlık Bilimleri Enstitüsü, Ankara.

Hughes, J. N., Cavell, T. A., \& Willson, V. (2001). Further support for the developmental significance of the quality of the teacher-student relationship. Journal of School Psychology, 39(4), 289-301. https://doi.org/10.1016/S0022-4405(01)00074-7

Kalayc1, Ş. (Ed.) (2008). SPSS Uygulamalı çok değişkenli istatistik teknikleri. Ankara: Asil.

Koyunlu, Ü. Z., \& Dere, Z. (2019). Okul öncesi öğretmen adaylarının FETEMM farkındalıklarının değerlendirilmesi. Erzincan Üniversitesi Eğitim Fakültesi Dergisi, 21(1), 44-55. https://doi.org/10.17556/erziefd.481586

Lori, G. I. (2007). Early childhood development: a powerful equalizer. World Health Organization Commission on the Social Development of Health.

Macy, M. G., \& Bricker, D. D. (2007). Embedding individualized social goals into routine activities in inclusive early childhood classrooms. Early Child Development and Care, 177(2), 107-120. https://doi.org/10.1080/03004430500337265

McDonnell, J., Thorson, N., Disher, S., Mathot-Buckner, C., Mendel, J., \& Ray, L. (2003). The achievement of students with developmental disabilities and their peers without disabilities in inclusive settings: an exploratory study. Education and Treatment of Children, 26(3), 224-236.

Ministry of National Education. (2013). Preschool Education Program. Ankara.

Noh, J., Allen, D., \& Squires, J. (2009). Use of embedded learning opportunities within daily routines by early intervention/early childhood special education teachers. International Journal of Special Education, 24(2), $1-10$.

Ogan, A. T. (2005). An investigation of the effects of make-believe play training on the development of self-regulation in Head Start children. Doctoral dissertation, Illinois State University, Illinois.

Özkür, F. (2019). Embedded öğrenme temelli hareket eğitim programının 5 yaş grubu çocukların görsel motor, davranış düzenleme ve sosyal beceri gelişimlerine etkisinin incelenmesi. Doktora Tezi. Gazi Üniversitesi Eğitim Bilimleri Enstitüsü, Ankara.

Pintrich, P. R. (2000). The role of goal orientation in self-regulated learning. In M. Boekaerts, P. R. Pintrich \& M. Zeidner (Eds.), Handbook of Self-Regulation (pp. 451-502). San Diego, CA: Academic. https://doi.org/10.1016/B978-012109890-2/50043-3

Pretti-Frontczak, K., \& Bricker, D. D. (2004). An activity-based approach to early intervention (3rd ed.). Baltimore, MD: Brookes.

Purtaş, Ö. (2017). Okul öncesi eğitim programı hareket ve bütünleştirilmiş hareket etkinliklerinin çeşitli 
değişkenler açısından incelenmesi. Yayımlanmamış yüksek lisans tezi, Gazi Üniversitesi Eğitim Bilimleri Enstitüsü, Ankara.

Purtaş, Ö., \& Duman, G. (2017a). Analyzing parkours of movement activity plans designed for children in early childhood education. Social Sciences Studies Journal, 3(10), 1366-1372. https://doi.org/10.26449/sssj.152

Purtaş, Ö., \& Duman, G. (2017b). The examination of movement activity plans applied in early childhood education in terms of various variables. Turkish Journal of Primary Education, 2(1), 11-29.

Rakap, S. (2017). Okul öncesi dönemde kaynaştırma eğitimi uygulamalarının desteklenmesinde doğal öğretim yaklaşımları. Özel Ĕgitim Dergisi, 18(3), 471-492. https://doi.org/10.21565/ozelegitimdergisi.319665

Rueda, M. R., Rothbart, M. K., McCandliss, B. D., Saccomanno, L., \& Posner, M. I. (2005). Training, maturation, and genetic influences on the development of executive attention. Proceedings of the National Academy of Sciences, 102, 391-936. https://doi.org/10.1073/pnas.0506897102

Sezgin, E. (2016). Çocukların davranışsal öz-düzenleme becerilerine oyun temelli eğitimin etkisinin incelenmesi. Doktora Tezi, Gazi Üniversitesi Eğitim Bilimleri Enstitüsü, Ankara.

Sezgin, E., \& Demiriz, S. (2016). Çocuk davranış değerlendirme ölçeği’ nin (çoddö) türkçe' ye uyarlanması: geçerlik ve güvenirlik çalışması. Mersin Üniversitesi Eğitim Fakültesi Dergisi, 12(2), 702-718. https://doi.org/10.17860/efd.15303

Snyder, P., Denney, M., Pasia, C., Rakap, S., \& Crowe, C. (2011). Professional development in early childhood intervention: Emerging issues and promising approaches. In C. Groark (Series Ed.) \& L. Kaczmarek (Vol Ed.), Early Childhood intervention: Shaping the future for children with special needs and their families. Emerging trends in research and practise (pp. 169-204). Santa-Barbara, CA: Praeger /ABC-CLIO.

Snyder, P., Rakap, S., Hemmeter, M. L., McLaughlin, T., Sandall, S., \& McLean, M. (2015). Naturalistic instructional approaches in early learning: A systematic review of the empirical literature. Journal of Early Intervention, 37(1), 69-97. https://doi.org/10.1177/1053815115595461

Sparling, J., Ramey, C. T., \& Ramey, S. L. (2007). The Abecedarian experience. In M. E. Young (Ed.), Early Child Development-From measurement to action: A priority for growth and equity (pp. 81-99). Washington, DC: The World Bank.

Zimmerman, B. J. (2002). Becoming a self regulated learner: an owerview. Theory into Practice, 41(2), 64-70. https://doi.org/10.1207/s15430421tip4102_2

\section{Note}

Research data were partially excerpted from the doctoral thesis of the corresponding author.

\section{Copyrights}

Copyright for this article is retained by the author, with first publication rights granted to the journal.

This is an open-access article distributed under the terms and conditions of the Creative Commons Attribution license (http://creativecommons.org/licenses/by/4.0/). 